\title{
Ameliorating effect of Bee Pollen against Anti- Tuberculosis drugs (Rifampicin and Isoniazid) Induced Toxicity on Haematology of Sprague Dawley Rats
}

\author{
Umesh Bharti ${ }^{1}$, Neelima R. Kumar ${ }^{2}$, Jaspreet Kaur ${ }^{3}$ \\ ${ }^{1}$ PG Govt. College for Girls, Sector-11, Chandigarh, India \\ ${ }^{2}$ Department of Zoology, Panjab University, Chandigarh, India \\ ${ }^{3}$ Department of Biotechnology, UIET, Panjab University, Chandigarh, India
}

\begin{abstract}
Experimental male SD rats weighing $180 \pm 20 \mathrm{~g}$ were randomly assigned into eight groups comprising of drug treated and bee pollen administered rats in selected test concentrations. Haemoglobin (Hb), red blood cellcount (RBC Count) and white blood cell count (WBC Count) were then evaluated using standard techniques after 30 days of treatment. Result indicated that bee pollen feeding helped to improve blood parameters in normal rats. Further, the drugs rifampicin and isoniazid alone as well as in combination significantly lowered blood indices indicating toxicity. However, co- administration of bee pollen (100 $\mathrm{mg}$ bee pollen $/ \mathrm{kg}$ body weight) definitely helped to ameliorate the toxic effects by restoring tested values to near normal.
\end{abstract}

Keywords: Bee Pollen, Rifampicin, Isoniazid, Haemoglobin, RBC Count and WBC count

\section{Introduction}

Honey bees collect pollen from plant anthers, mix it with asmall dose of the secretion fromsalivary glands or nectar, andplace it in specific baskets (corbiculae) which are situated onthe tibia of their hind legs. Thefield bees collect and transport the bee pollen to the hive. Bee pollen is rich in carotenoids, flavonoid and phytosterols. The exact profile varies depending on the plant sources and growing conditions and the honey bee species.However, betacarotene, beta sitosterol, isohammetin, kaempferol, lycopene, quercetin and rutin are consistently present (Campos et al., 2008). The antioxidant activity of flavonoids present in bee pollen has been shown to be capable of scavenging free radicals (Survswaranet al., 2007).Drugs used for the treatment of tuberculosis have been reported to cause major adverse reaction and significant morbidity leading to a compromised treatment regimen. Side-effects such as hepatitis, dyspepsia, exanthema and arthralgia were responsible for termination of therapy in up to $23 \%$ of patients during the intensive phase (Schaberget al., 1996).Several studies had reported that leukopenia, eosinophilia, haemolytic anaemia along with hepatotoxicity, fatigue, dizziness, headache and dyspnoea, occurred after Rifampicin and Isoniazid administration (Forget and Menzies, 2006; Baciewicz et al., 2008).The aim of this study was to evaluate the antioxidant effects of dietary bee pollen supplementation against toxicity induced by antituberculosis drugs Rifampicin and Isoniazid in Sprague Dawley rats.

\section{Material and Methods}

\subsection{Experimental Animals}

Male Sprague Dawley rats of body weight in the range of $180 \pm 20$ gm were obtained from the central animal house of Panjab University, Chandigarh. Animals were kept in polypropylene cages bedded with rice husk in 12 hours light/dark cycle under hygienic conditions. They were fed with standard pellet feed (purchased from Ashirwaad Industries, Sector-15, Chandigarh) and water ad libitum.

\subsection{Collection and Preparation of Bee Pollen Extract}

Bee Pollen was collected by installing pollen trap in Langstroth bee hives maintained in an apiary at Majri village near old Panchkula, Haryana. Aqueous extract of pollen was prepared (Yamaguchi et al., 2007).

\subsection{Drugs}

Rifampicin and Isoniazid drugs were purchased fromHimedia

\subsection{Experimental Protocol}

The animals were randomly assigned into eight (8) groups of six rats (Male Sprague Dawley) each and treated as follows:

Group 1: Control group

Group 2: 100mgbee pollen /kg body weight(aqueous extract orally, once daily)

Group 3: 100mg Rifampicin/kg body weight(orally, once daily)

Group 4: $100 \mathrm{mg}$ bee pollen $/ \mathrm{kg}$ body weight $+100 \mathrm{mg}$ Rifampicin/kg body weight (orally, once daily) 


\section{International Journal of Science and Research (IJSR) \\ ISSN (Online): 2319-7064}

Index Copernicus Value (2013): 6.14 | Impact Factor (2015): 6.391

Group 5: 50mg Isoniazid / kg body weight (orally, once daily)

Group 6: 100mg bee pollen / kg body weight + 50mg Isoniazid /kg body weight (orally, once daily)

Group 7: 100mg Rifampicin+ 50mg Isoniazid /kg body weight (orally, once daily)

Group 8: $100 \mathrm{mg}$ bee pollen $/ \mathrm{kg}$ body weight $+100 \mathrm{mg}$ Rifampicin+ 50mg Isoniazid /kg body weight (orally, once daily)

Oral gavages using a metal oropharyngeal canula and syringe were employed in the administration of the bee pollen extract, Rifampicin and Isoniazid once daily for 30days. The animals were sacrificed by cervical dislocation after 30 days of treatment.

\subsection{Blood Collection}

Blood samples were taken from each rat by terminal bleeding from the heart with syringe rinsed with EDTA and transferred into a clean EDTA container (thoroughly mixed) ready for Haematological investigations.

\subsubsection{Haemoglobin Estimation}

Haemoglobin was estimated using the Sahli'sHaemoglobin meter Principle: Haemoglobin present in the blood when reacts with $\mathrm{N} / 10 \mathrm{HCl}$ gets converted into acid hematin which gives golden brown colour. More the amount of haemoglobin more will be the intensity of colour.

Procedure:

- The graduated tube of Sahli'sHaemoglobin meter was washed with distilled water and dried.

- To the graduated tube added $2 \mathrm{ml}$ of $\mathrm{N} / 10 \mathrm{HCl}$ with the help of dropper.

- $0.2 \mathrm{ml}$ of blood was sucked with the help of auto pipette and mixed with $\mathrm{N} / 10 \mathrm{HCl}$ present in the graduated tube.
- Blood was mixed thoroughly with the help of auto pipette and was left for 2 minutes.

- The solution was diluted with drop wise addition of distilled water till the colour matched with the colour of standard tubes provided in Sahli'sHaemoglobin meter in bright diffuse day light with a sheet of white paper as background.

- Reading was noted from the graduated tube (bottom of the meniscus) which provided value to find amount of haemoglobin (gm/dl).

\subsubsection{Red Blood Cell Count (RBC Count):}

Principle; Number of red blood cells in blood is in millions therefore, blood is diluted 200 times with the help of RBC diluting fluid( Hayem's Solution: Sodium chloride $1 \mathrm{~g}$,Sodium sulphate $5 \mathrm{~g}$, Corrosive sublimate $0.5 \mathrm{~g}$ and Distilled water 200ml.). Then with the help of Neubauerhaemocytometer the number of RBC's is counted under light microscope

Procedure:

- Blood was sucked in RBC pipette up to the mark 0.5. It was followed by sucking Hayem' solution up to the 101 mark.

- The solution was thoroughly mixed by rotating the pipette for about one minute.

- After discarding first few drops of solution from the pipette, two drops were loaded on the counting chamber of Haemocytometerand covered with coverslip.

- When the cells settled out of suspension, the Haemocytometer was placed under the microscope for counting of RBC.

- The RBC were counted from five Squares out of twenty five squares in accordance to the Thoma counting rule. Each square had sixteen cells.

The final result wasexpressed as the number of cells per litre of blood using the formula below:

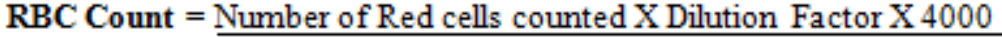 (per cu mm) 80 (Number of small squares counted)}

\subsubsection{Total White Blood Cell Count (TLC)}

Principle: Number of white blood cells in blood is in thousands therefore, blood is diluted 20 times with the help of WBC diluting fluid(Turk's Fluid:1\% solution of gentian violet in water $-1 \mathrm{ml}$,glacial acetic acid $-1.5 \mathrm{ml}$., Distilled water -98ml.).Then with the help of Neubauer haemocytometer the WBC's are counted under light microscope.

Principle:

- Blood was sucked in WBC pipette up to mark 0.5 followed by sucking the Turk's solution to the 11 mark.

- The solution was thoroughly mixed by rotating the pipette for about one minute.
- After discarding first few drops of solution from the pipette, two drops were loaded on the counting chamber of Haemocytometer and covered with coverslip.

- When the cells settled out of suspension, the Haemocytometer was placed under the microscope for counting of WBC

- The WBC were counted from four corner squares and each square had sixteen cells.

The numbers of cells present in the 4 corner $1 \mathrm{~mm}^{2}$ areas (total area of $4 \mathrm{~mm}^{2}$ ) were counted in accordance to the Thoma counting

Total number of $\mathbf{W B C}=$ Number of cells counted X Dilution X10

$$
\text { (per cu mm) } 4 \text { (Number of } 1 \text { square ml. counted) }
$$

\subsection{Statistical Analysis}

Data were presented as mean $\pm \mathrm{SD}$ and analysed using one way analysis of variance (ANOVA). Pvalues $<0.05$ were considered significant

\section{Results and Discussions}

Tuberculosis is a leading health problem in developing countries and is the major cause of death worldwide. Rifampicin and Isoniazid are important first line drugs used 


\section{International Journal of Science and Research (IJSR) \\ ISSN (Online): 2319-7064 \\ Index Copernicus Value (2013): 6.14 | Impact Factor (2015): 6.391}

against Tuberculosis. Since the drugs used in treatment of tuberculosis have been reported to show toxic side effects, studies have been performed to attempt to reduce the toxicity by using various herbal products like Garlic (Nasiru. et al., 2012),Silymarin (Eminzade.et al.,2008) and Ocimum (Razvi. et al.,2003).

The beneficial effect of bee pollen in case of haemolytic anaemia in mice and ratswas investigated by Wang et al.,(1993).who also reported stimulation of the haematopoietic system. Supplementation of bee pollen resulted in an increase in haemoglobin level and alleviated the negative consequences of iron deficiency by improving the absorption and utilisation of nutritional iron (Haro, et al., 2000).In the light of such reports, the present study was undertaken to test the therapeutic protective properties against anti- tuberculosis drug toxicity.

\subsection{Effect of bee pollen onhaemoglobin}

Haemoglobin level of the animals given bee pollen extract (100mg/kg body weight) was $15.65 \pm 0.13$ which was significantly higher than the control group $(15.1 \pm 0.18)$ at $\mathrm{P}<0.001$.A significant decrease $(23 \%)$ in the level of Haemoglobin was observed in $(100 \mathrm{mg} / \mathrm{kg}$ body weight)Rifampicin,18\% decrease in Isoniazid $(50 \mathrm{mg} / \mathrm{kg}$ body weight) and $12 \%$ decreasein combination Rifampicin(100 mg/kg body weight)plusIsoniazid (50 mg/kg body weight) treated groups. When however the treatment was supplemented with bee pollen (100mg/kg body weight) drastic increase was noticed with respect to Rifampicin (22.6\%), Isoniazid (17\%) and Rifampicin plus Isoniazid (9.9\%) administered after 30 days of treatment.

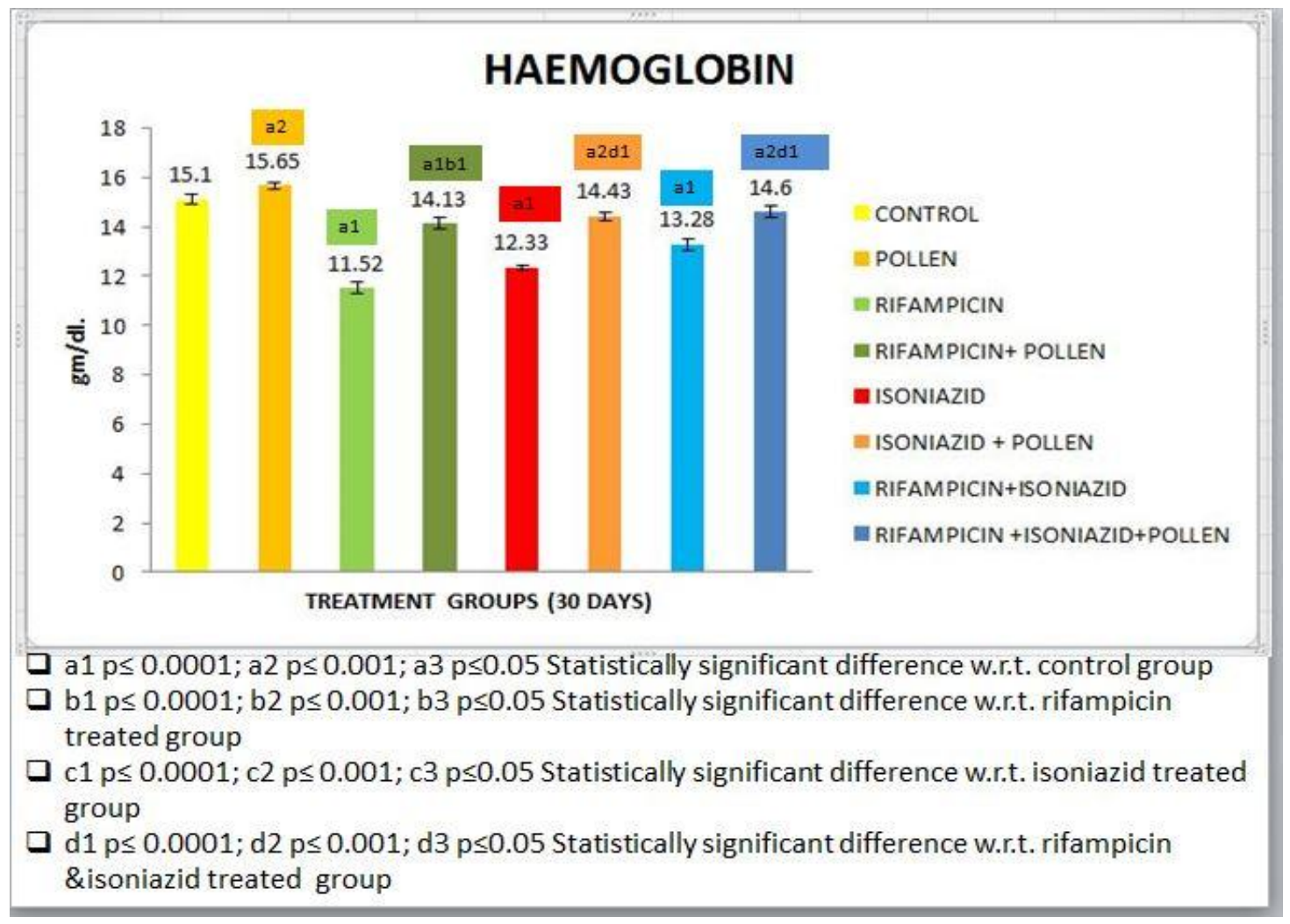

Histogram1: Haemoglobin Level in Treatment Groups

On giving bee pollen the level of haemoglobin was found to be near normalas shown in table 1.

\section{TABLE1: HAEMOGLOBIN LEVEL OF EXPERIMENTAL MALE SD RATS}

\begin{tabular}{|c|c|c|c|c|c|c|c|c|}
\hline $\begin{array}{l}\text { Treatment } \\
\text { Groups } \\
\text { (30 Days) }\end{array}$ & Control & Pollen & Rifampicin & $\begin{array}{l}\text { Rifampicin } \\
\text { +Pollen }\end{array}$ & Isoniazid & $\begin{array}{l}\text { Isoniazid } \\
+ \text { Pollen }\end{array}$ & $\begin{array}{l}\text { Rifampicin } \\
+ \text { Isoniazid }\end{array}$ & $\begin{array}{l}\text { Rifampicin } \\
+ \text { Isoniazid } \\
+ \text { Pollen }\end{array}$ \\
\hline $\begin{array}{l}\text { Haemoglobin } \\
(\mathrm{gm} / \mathrm{dl})\end{array}$ & $\begin{array}{l}15.1 \\
\pm 0.18\end{array}$ & $\begin{array}{l}15.65 \\
\pm 0.13\end{array}$ & $\begin{array}{l}11.52 \\
\pm 0.22\end{array}$ & $\begin{array}{l}14.13 \\
\pm 0.25\end{array}$ & $\begin{array}{l}12.33 \\
\pm 0.13\end{array}$ & $\begin{array}{l}14.43 \\
\pm 0.17\end{array}$ & $\begin{array}{l}13.28 \\
\pm 0.22\end{array}$ & $\begin{array}{l}14.6 \\
\pm 0.21\end{array}$ \\
\hline $\begin{array}{l}\text { Values } \\
\text { Represent \% } \\
\text { Change w.r.t. } \\
\text { Control }\end{array}$ & & $(3.6 \%)$ & $(-23.7 \%)$ & $(-6.4 \%)$ & $(-18.3 \%)$ & $(-4.4 \%)$ & $(-12 \%)$ & $(-3.3 \%)$ \\
\hline $\begin{array}{l}\text { Values } \\
\text { Represent \% } \\
\text { Change w.r.t. } \\
\text { Drug }\end{array}$ & & & & $(22.6 \%)$ & & [17\% & & (9.9\%) \\
\hline
\end{tabular}




\section{International Journal of Science and Research (IJSR) \\ ISSN (Online): 2319-7064 \\ Index Copernicus Value (2013): 6.14 | Impact Factor (2015): 6.391}

\subsection{Effect of bee pollen on red blood cell count}

The RBC count of control rat was8.15 \pm 0.21 million / cu.mm., when anti tuberculosis drugs were given significant decrease was observed being 9.30\% with rifampicin, $6.1 \%$ with isoniazid and 5.03\% with Rifampicin plus Isoniazid together. On treatment with bee pollen at a dose of
$100 \mathrm{mg} / \mathrm{kg}$ body weight, with Rifampicin the level were increased to8.47 \pm 0.14 million/cu mm, with Isoniazid $7.65 \pm 0.21 \mathrm{million} / \mathrm{cu} \mathrm{mm}$ and with Rifampicin and Isoniazid together red blood cell count was $8.45 \pm 45$ million/cumm as shown in Table 2.

\section{TABLE2: RBC COUNT OF EXPERIMENTAL MALE SD RATS}

\begin{tabular}{|c|c|c|c|c|c|c|c|c|}
\hline $\begin{array}{l}\text { Treatment } \\
\text { Groups } \\
\text { (30 Days) }\end{array}$ & Control & Pollen & Rifampicin & $\begin{array}{l}\text { Rifampicin } \\
+ \text { Pollen }\end{array}$ & Isoniazid & $\begin{array}{l}\text { Isoniazid } \\
\text { +Pollen }\end{array}$ & $\begin{array}{l}\text { Rifampicin } \\
\text { +Isoniazid }\end{array}$ & $\begin{array}{l}\text { Rifampicin } \\
\text { +Isoniazid } \\
+ \text { Pollen }\end{array}$ \\
\hline $\begin{array}{l}\text { Rbc Count } \\
\text { (million/cu.mm) }\end{array}$ & $\begin{array}{l}8.15 \\
\pm 0.21\end{array}$ & $\begin{array}{l}9.17 \\
\pm 0.13\end{array}$ & $\begin{array}{l}7.39 \\
\pm 0.14\end{array}$ & $\begin{array}{l}8.47 \\
\pm 0.10\end{array}$ & $\begin{array}{l}7.65 \\
\pm 0.21\end{array}$ & $\begin{array}{l}8.81 \\
\pm 0.17\end{array}$ & $\begin{array}{l}7.74 \\
\pm 0.21\end{array}$ & $\begin{array}{l}8.45 \\
\pm 0.12\end{array}$ \\
\hline $\begin{array}{l}\text { Values Represent } \\
\text { \% Change w.r.t. } \\
\text { Control }\end{array}$ & & $(12.5 \%)$ & $(-9.30 \%)$ & $(3.9 \%)$ & $(-6.1 \%)$ & $(7.81 \%)$ & $(-5.03 \%)$ & $(3.7 \%)$ \\
\hline $\begin{array}{l}\text { Values Represent } \\
\text { \% Change w.r.t. } \\
\text { Drug }\end{array}$ & & & & $14.60 \%$ & & $15.16 \%$ & & $9.23 \%$ \\
\hline
\end{tabular}

Rise in RBC count on treatment with bee pollen was statistically significant as shown in the Histogram 2.

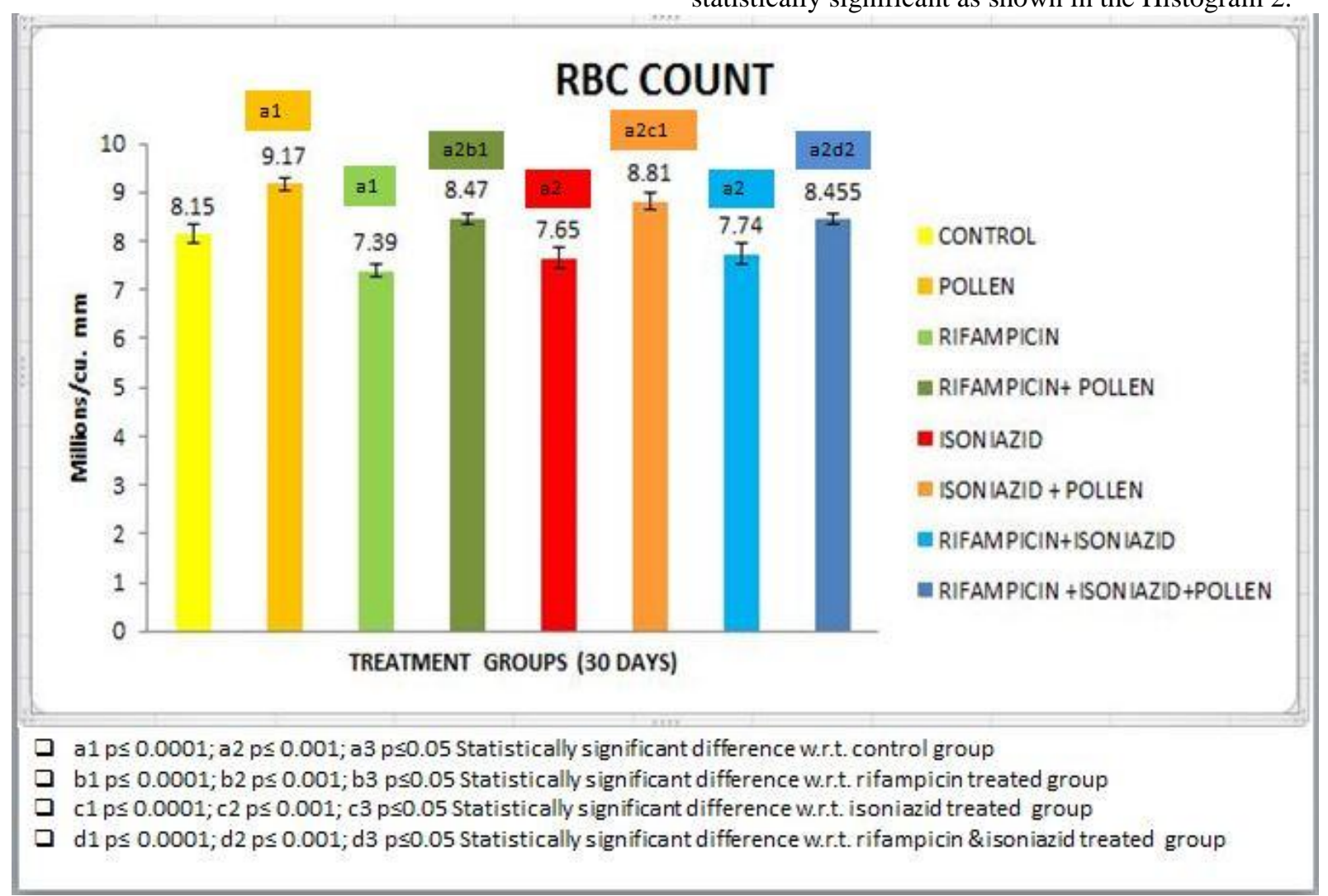

\section{Histogram 2: RBC COUNT IN TREATMENT GOUPS}

\subsection{Effect of bee pollen on white blood cell count}

The total leucocyte count for normal rat was found to be $18925 \pm 250$. Leuconemia was observed in drug treated rats with decrease of $37.78 \%$ (Rifampicin), $26.81 \%$ (Isoniazid) and $37.51 \%$ (Rifampicin and Isoniazid together). 
International Journal of Science and Research (IJSR)
ISSN (Online): 2319-7064

Index Copernicus Value (2013): 6.14 | Impact Factor (2015): 6.391

\section{TABLE3: TOTAL LEUCOCYTE COUNT OF EXPERIMENTAL MALE SD RATS}

\begin{tabular}{|c|c|c|c|c|c|c|c|c|}
\hline $\begin{array}{l}\text { Treatment } \\
\text { Groups } \\
\text { (30 Days) }\end{array}$ & Control & Pollen & Rifampicin & $\begin{array}{l}\text { Rifampicin } \\
\text { +Pollen }\end{array}$ & Isoniazid & $\begin{array}{l}\text { Isoniazid } \\
+ \text { Pollen }\end{array}$ & $\begin{array}{l}\text { Rifampicin } \\
\text { +Isoniazid }\end{array}$ & $\begin{array}{l}\text { Rifampicin } \\
+ \text { Isoniazid } \\
+ \text { Pollen }\end{array}$ \\
\hline$\overline{T L C}$ & 18925 & 23100 & 11775 & 17850 & 13850 & 16550 & 11825 & 18300 \\
\hline (percc.mm) & \pm 250 & \pm 258 & \pm 262 & \pm 310 & \pm 208 & \pm 288 & \pm 170 & \pm 294 \\
\hline $\begin{array}{l}\text { Values } \\
\text { Represent \% } \\
\text { Change w.r.t. } \\
\text { Control }\end{array}$ & & $22 \%$ & $-37.78 \%$ & $-5.60 \%$ & $-26.81 \%$ & $-12.54 \%$ & $-37.51 \%$ & $-3.30 \%$ \\
\hline $\begin{array}{l}\text { Values } \\
\text { Represent \% } \\
\text { Change w.r.t. } \\
\text { Drug }\end{array}$ & & & & $51.59 \%$ & & $19.49 \%$ & & $54.75 \%$ \\
\hline
\end{tabular}

After thirty days of treatment with bee pollen significant increase was seen in WBC count.

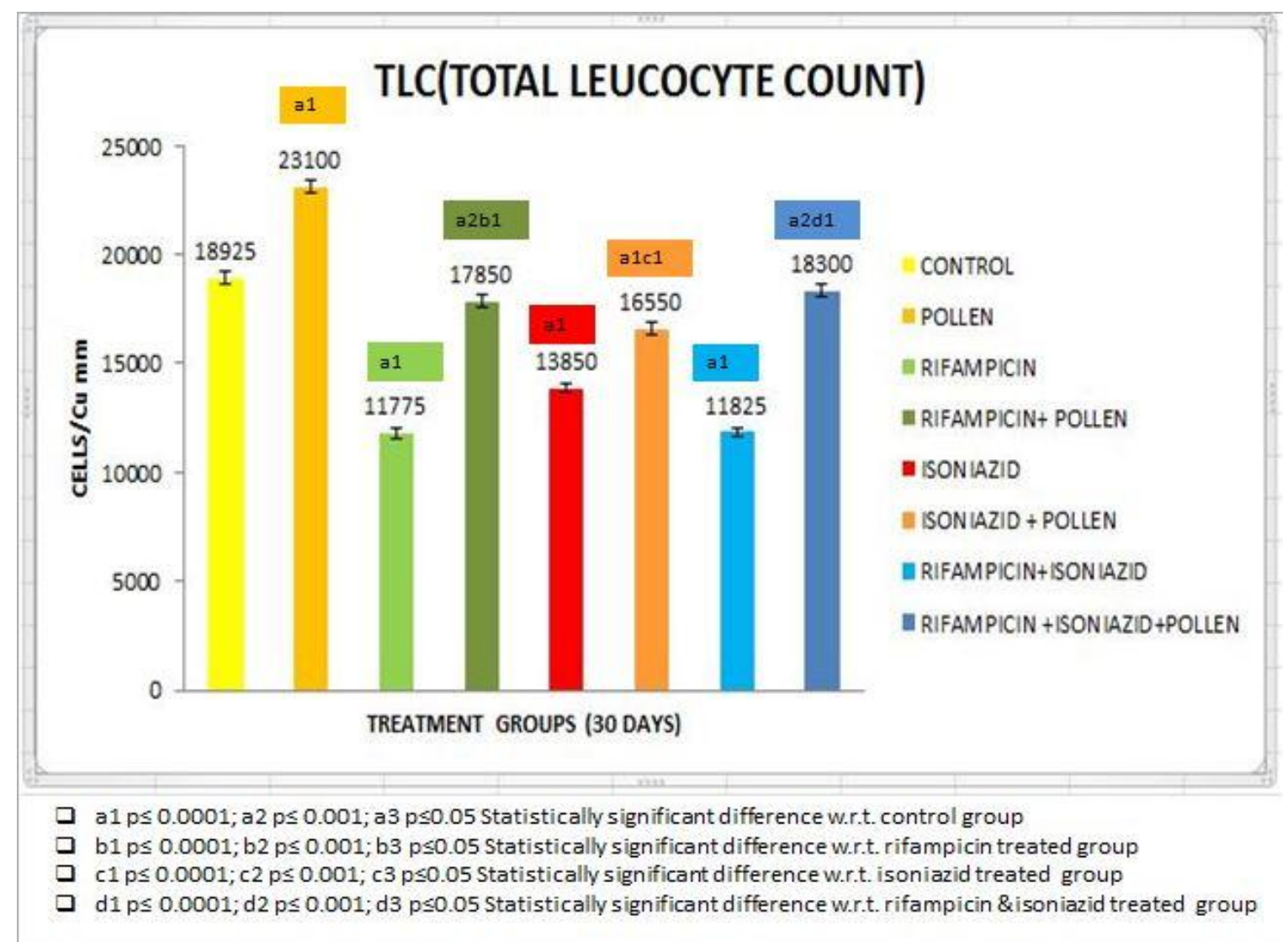

Histogram 3: TLC in treatment goups

\section{Conclusion}

The induction of haematological response was studied through haemoglobin estimation, RBC Count and Total Leucocyte Count in different groups of SD Rats. Anaemia was observed in anti-tuberculosis drug treated animals. There was drastic decrease in haemoglobin count, RBC count and WBC count when animals were treated with Rifampicin, Isoniazid and Rifampicin and Isoniazid in combination. On supplementing bee pollen with antituberculosis drugs significant increase in the level of haemoglobin, RBC count and WBC count was recorded. This supports the hypothesis that bee pollen shows ameliorative effect by normalising the levels of treated blood parameters.

\section{References}

[1] Baciewicz, A.M.; Chrisman, C.R.; Finch,C.K.and Self, T.H. (2008). Update on Rifampin and Rifabutin drug interactions. Am. J. Med. Sci. 335(2):126-36.

[2] Bonvehí, S.J.;Torrentó,S.M.andLorente, C.E. (2001). Evaluation of polyphenolic and flavonoid compounds in honeybee-collected pollen produced in Spain. J. Agric. Food Chem. 49:1848-1853. 
[3] Campos, M.;Bogdanov, S.; Almeida, M. L.; Szczesna, T.;Mancebo, Y.;Frigerio, C.and Ferreira, F. (2008). Apicultural Research Bee World. 47(2): 154-161.

[4] Eminzade, S.; Uras, F. and Izzettin, F.V.(2008). Silymarin protects liver against toxic effects of antituberculosis drugs in experimental animals. Nutrition \& Metabolism.5; 1-8.

[5] Forget, E.J. and Menzies, D.(2006). Adverse reactions to firstlineantituberculosis drugs. Expert Opin. Drug Saf. 5(2):231-49.

[6] Haro, A.;López-Aliaga, I.;Lisbona, F.;Barrionuevo, M.;Alférez, M.J.and Campos, M.S.(2000). Beneficial effect of pollen and/or propolis on the metabolism of iron, calcium, phosphorus, and magnesium in rats with nutritional ferropenicanemia. J. Agric. Food Chem. 48: 5715-5722.

[7] Nasiru, A.; Hafsat, I.G. and Sabo, A.A.(2012). Effect of anti- tuberculosis drugs co-administered with garlic homogenate on rat liver enzymes. IPCBEE. 40: 96-98.

[8] Razvi.S.U.;Kothekar M.; Anantrao; Jaju, B. and Mateenuddin, M.D. (2003). Effect of Ocimum sanctum leaf extract on hepatotoxicity induced by antitubercular drugs in rats. Indian J. Physical Pharmacol. 47(4): 465470.

[9] Schaberg, T.;Rebham, K.and Lode, H. (1996). Risk factors for side-effects of isoniazid, rifampicin and pyrazinamide in patients hospitalized for pulmonary tuberculosis. EurRespir J. 9: 2026-30.

[10] Surveswaron, S.; Cai, Y.Z.; Carke, H. and Sun, M. (2007). Systematic evaluation of natural phenolic antioxidants from 133 Indian medicinal plant. Food Chem. 102: 938-953.

[11] Wang, M.S.; Fan, H.F.and Xu, H.J (1993). Effects of bee pollen on blood and hemopoietic system in mice and rats.Chin. Tradit. Herb. Drugs. 24: 588-591.

[12] Yamaguchi, M.;Hamamoto, R.; Uchiyama, S.andIshiyama, K. (2007). Preventive effects of Bee pollen Cistus ladaniferus extract on bone loss in streptozotocin-diabetic rats in vitro.J. Health Sci. 53(2): 190-195. 